\title{
Latitudinal gradient in the distribution of intertidal barnacles of the Tetraclita species complex in Asian waters
}

\author{
Benny Kwok Kan Chan ${ }^{1,2}$, Akihisa Murata ${ }^{3}$, Pei-Fen Lee ${ }^{4, *}$ \\ ${ }^{1}$ The Swire Institute of Marine Science, Department of Ecology \& Biodiversity, The University of Hong Kong, Hong Kong SAR \\ ${ }^{2}$ Research Centre for Biodiversity, Academia Sinica, Taipei 115, Taiwan ROC \\ ${ }^{3}$ Coastal Branch, Natural History Museum and Institute, Katsuura, Chiba Prefecture 260-8682, Japan \\ ${ }^{4}$ Institute of Ecology and Evolutionary Biology, National Taiwan University, Taipei 106, Taiwan ROC
}

\begin{abstract}
Barnacles are a major space occupier in the intertidal zone and are good model organisms to study the biogeography of intertidal invertebrates. In the present study, we used quantitative transect sampling to study the geographical distribution of the common rocky shore barnacles Tetraclita kuroshioensis, T. squamosa, T. japonica japonica and T. j. formosana at 19 sites covering the 3 large Asian marine ecosystems (Kuroshio Current, East China Sea and South China Sea) from $22^{\circ} 20^{\prime}$ to $35^{\circ} 00^{\prime} \mathrm{N}$. Tetraclita spp. showed spatial variations in geographical distribution. Species assemblages of $>60 \%$ similarity can be grouped into 4 distinct regions. On the Pacific coast of Japan T. j. japonica, T. j. formosana and T. kuroshioensis co-existed at the same tidal level, with T. j. japonica at the highest abundance. In North Taiwan and Okinawa T. kuroshioensis and T. $j$. formosana were common. In East Taiwan, T. $j$. formosana was the dominant species and T. kuroshioensis occurred in low abundance. In South China, T. squamosa and T. j. japonica were found, but they occupied different tidal levels. T. $j$. formosana and T. kuroshioensis were abundant in West Pacific waters, suggesting that their larval pool is associated with the Kuroshio Current. T. squamosa was distributed along the South China coast and it is possible that their larvae were transported mainly by the South China Sea Surface Current. T. j. japonica had high abundance in both Japan and South China, but with very low abundance at the Pacific shores between these 2 locations. There may be a physical and genetic boundary between the northern and southern populations in the Pacific Ocean and further studies of Tetraclita spp. in the Asian region should focus on population genetics.
\end{abstract}

KEY WORDS: Barnacles $\cdot$ Tetraclita $\cdot$ Rocky shores $\cdot$ Biogeography $\cdot$ Oceanography

\section{INTRODUCTION}

Intertidal invertebrates often have a planktonic larval phase and a benthic adult stage. The geographical distribution of intertidal communities can therefore be affected by the larval supply, larval mortality, larval dispersal range and post-settlement mortality (Morgan 2001). Larval supply and dispersal range can be influenced by oceanographic processes (e.g. oceanographic current patterns and upwelling), resulting in variation in geographical distribution (Connolly et al. 2001). Barnacles have often been used as model species to study the patterns and processes affecting geographical distribution as they are the major space occupier in the intertidal zone and have wide geographical distribution (see Connolly et al. 2001, Morgan 2001).

Tetraclita spp. are common rocky shore barnacles in the Indo-Pacific region (Pilsbry 1916, Newman \& Ross 1976). In the past, T. squamosa was considered to consist of 3 sub-species (T. squamosa squamosa, T. s. japonica and T. s. formosana) in NW Pacific waters. Using morphological analysis and molecular techniques, the sub-species of T. squamosa were separated into 3 species: T. kuroshioensis (synonymous with T. pacifica, see 
Chan et al. 2007a,b); T. squamosa Bruguière 1789; and T. japonica (Yamaguchi 1987, Hasegawa et. al. 1996, Chan 2001, 2003, Chan et al. 2007a,b). T. japonica Pilsbry 1916 and T. formosana Hiro 1939 were previously identified as 2 species but Chan et al. (2007c) revealed no differentiation between their mitochondrial (COI, 12S) and nuclear (ITS1) DNA. They were therefore grouped into sub-species of T. japonica as T. japonica japonica Pilsbry 1916 and T. j. formosana Hiro 1939, based on their differences in parietes (shell) colour and geographical distribution. Major diagnostic morphological differences of Tetraclita spp. in the NW Pacific waters are in the colour of the parietes, shape of the opercular plates, the patterns on the tergal-scutal flaps and the setal types of the first and third maxillipeds (see Yamaguchi 1987, Chan 2001, Chan et al. 2007a,b).

The geographical distribution record of Tetraclita spp. in Asia has, however, often been reported qualitatively (Hiro 1939, Utinomi 1954, Ren \& Liu 1979, Yamaguchi 1987), resulting in confusion as to where they can be found, and making it difficult to compare their abundance between locations; this may be related to interactions of the patterns of larval supply and oceanographic currents (see Morgan 2001). Utinomi (1949, 1954) claimed that $T$. japonica japonica were completely absent from Taiwan, whilst Yamaguchi (1987) documented the existence of T. j. japonica at one site on the northern coastline of Taiwan. T. squamosa was reported to be distributed in the Indo-Pacific, but recent studies showed that T. squamosa in the Pacific Ocean was a separate species - T. kuroshioensis (see Chan et al. 2007a). The geographical distribution of T. squamosa and T. kuroshioensis was, therefore, uncertain.

The zonation pattern and geographical distribution of Tetraclita spp. in the Pacific region appears to vary along the latitudes, which could result from variations in reproductive season, oceanographic currents, climate, larval supply and recruitment (Miron et al. 1999, Morgan 2001, Herbert et al. 2007). The aim of the present study was to obtain further insight into the biogeography of intertidal communities in the NW Pacific. Quantitative, stratified, transect surveys were conducted at locations along the latitudinal gradient from Honshu, Japan, in the NW Pacific to SE Asia (including the Okinawa island, Taiwan, Xiamen and Hong Kong) to test whether the geographical distributions of $T$. kuroshioensis, T. squamosa, T. japonica japonica and T. j. formosana vary across latitudes.

\section{MATERIALS AND METHODS}

Study sites and timing. We studied barnacle distribution from Japan, Taiwan and mainland China along the latitude from $22^{\circ} 20^{\prime}$ to $35^{\circ} 00^{\prime} \mathrm{N}$ from 2003 to 2005
(Table 1), except in Hong Kong where the data were collected by Chan et al. (2001) (Fig. 1). A total of 19 sites, distributed in 3 different large marine ecosystems (Kuroshio Current, East China Sea and South China Sea), were surveyed (Table 1).

Honshu, Japan: Sampling was conducted at Katsuura (KAT) (March 2004) and Kominato (KOM) (March 2004) in the Boso Peninsula (Table 1); at Shimoda (SHI) (October 2005) in the Izu Peninsula; and at Shirahama (SHA) (June 2005) in the Kii Peninsula (Fig. 1, Table 1). The rocks at all these study sites are sedimentary. Inshore seawater is oceanic with a high salinity of 30 to $33 \%$. Tides are semi-diurnal with a tidal range of $\sim 2 \mathrm{~m}$. The climate around the Boso and Izu Peninsulas is temperate and the hydrography is influenced by the cold Oyahio Current from the north and the warm Kuroshio Current from the south (Ishizaka et al. 1992). Waters at the south of Kii Peninsula are mainly influenced by the Kuroshio Current. Mean air temperature at KAT and $\mathrm{KOM}$ ranged from $7^{\circ} \mathrm{C}$ in winter to $28^{\circ} \mathrm{C}$ in summer.

Okinawa: At Okinawa Island, Japan, sampling was conducted in Sedake (SED) and Yaka (YK) (November 2003) (Table 1), in the Pacific Ocean, with a salinity of $33 \%$ all year round. Okinawa has a sub-tropical climate with semi-diurnal tides (max. tidal range can reach $2.5 \mathrm{~m}$ ). Hydrography in Okinawa Island is mainly influenced by the Kuroshio Current from the south (Fig. 1) (Ito et al. 1995).

Table 1. Site names and their abbreviations names and positions sampled for Tetraclita spp.; see also Fig. 1

\begin{tabular}{|c|c|c|}
\hline Site name & Abbrev. & $\begin{array}{l}\text { Latitude and } \\
\text { longitude }\end{array}$ \\
\hline \multicolumn{3}{|l|}{ Honshu, Japan } \\
\hline Katsuura, Boso Peninsula & KAT & $35^{\circ} 08^{\prime} \mathrm{N}, 140^{\circ} 18^{\prime} \mathrm{E}$ \\
\hline Kominato, Boso Peninsula & KOM & $35^{\circ} 07^{\prime} \mathrm{N}, 140^{\circ} 11^{\prime} \mathrm{E}$ \\
\hline Shimoda, Izu Peninsula & SHI & $34^{\circ} 39^{\prime} \mathrm{N}, 138^{\circ} 57^{\prime} \mathrm{E}$ \\
\hline $\begin{array}{l}\text { Shirahama, Wakayama, } \\
\text { Kii Peninsula }\end{array}$ & SHA & $33^{\circ} 40^{\prime} \mathrm{N}, 135^{\circ} 20^{\prime} \mathrm{E}$ \\
\hline \multicolumn{3}{|l|}{ Okinawa, Japan } \\
\hline Sedake & SED & $26^{\circ} 32^{\prime} \mathrm{N}, 128^{\circ} 05^{\prime} \mathrm{E}$ \\
\hline Yaka & YK & $26^{\circ} 27^{\prime} \mathrm{N}, 127^{\circ} 51^{\prime} \mathrm{E}$ \\
\hline \multicolumn{3}{|l|}{ Taiwan } \\
\hline Yeliou & YL & $25^{\circ} 12^{\prime} \mathrm{N}, 121^{\circ} 41^{\prime} \mathrm{E}$ \\
\hline Badoutz & $\mathrm{BAD}$ & $25^{\circ} 09^{\prime} \mathrm{N}, 121^{\circ} 45^{\prime} \mathrm{E}$ \\
\hline Bitou Cape & BTC & $25^{\circ} 07^{\prime} \mathrm{N}, 121^{\circ} 54^{\prime} \mathrm{E}$ \\
\hline Sandiu Cape & SDC & $24^{\circ} 59^{\prime} \mathrm{N}, 121^{\circ} 59^{\prime} \mathrm{E}$ \\
\hline Lai Lai & LL & $24^{\circ} 58^{\prime} \mathrm{N}, 121^{\circ} 57^{\prime} \mathrm{E}$ \\
\hline Beiguan & $\mathrm{BQ}$ & $24^{\circ} 54^{\prime} \mathrm{N}, 121^{\circ} 52^{\prime} \mathrm{E}$ \\
\hline Three Fairy Platforms & TFP & $23^{\circ} 07^{\prime} \mathrm{N}, 121^{\circ} 24^{\prime} \mathrm{E}$ \\
\hline Hsiao Yeliou & HYL & $22^{\circ} 49^{\prime} \mathrm{N}, 121^{\circ} 11^{\prime} \mathrm{E}$ \\
\hline Lanyu & LY & $22^{\circ} 01^{\prime} \mathrm{N}, 121^{\circ} 32^{\prime} \mathrm{E}$ \\
\hline \multicolumn{3}{|l|}{ Mainland China } \\
\hline Baiyu, Xiamen & BY & $24^{\circ} 22^{\prime} \mathrm{N}, 118^{\circ} 08^{\prime} \mathrm{E}$ \\
\hline Wuyu, Xiamen & WY & $24^{\circ} 21^{\prime} \mathrm{N}, 118^{\circ} 07^{\prime} \mathrm{E}$ \\
\hline Shek Mei Tau, Hong Kong & SMT & $22^{\circ} 16^{\prime} \mathrm{N}, 114^{\circ} 18^{\prime} \mathrm{E}$ \\
\hline Cape d'Aguilar, Hong Kong & $\mathrm{CD}$ & $22^{\circ} 12^{\prime} \mathrm{N}, 114^{\circ} 15^{\prime} \mathrm{E}$ \\
\hline
\end{tabular}




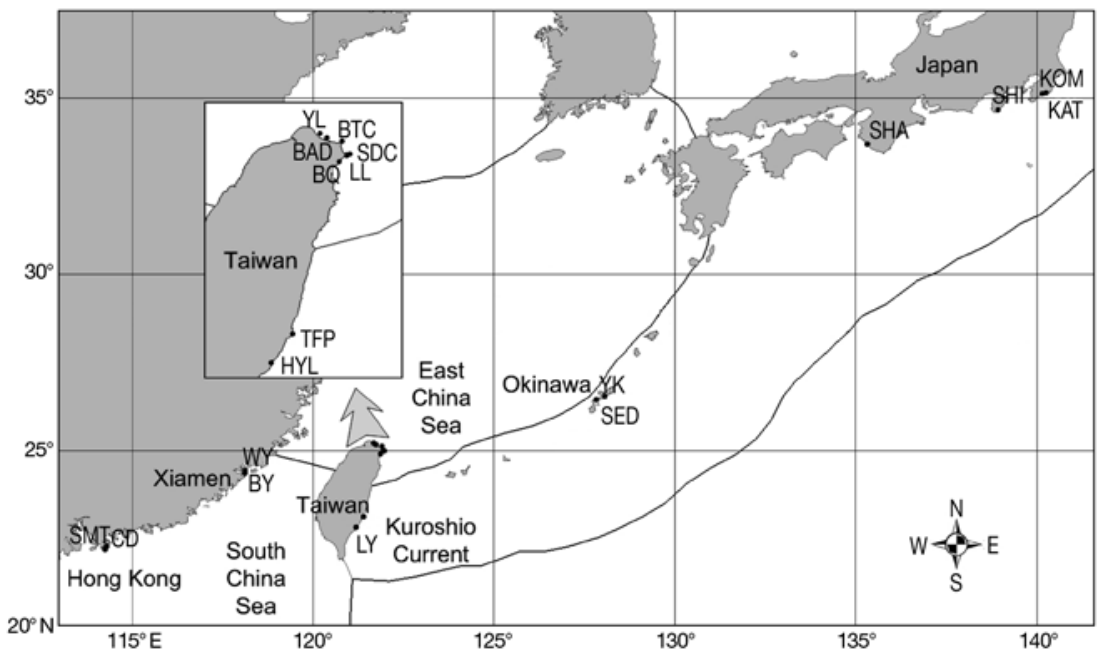

Fig. 1. Sampling locations of Tetraclita spp. in the NW Pacific and SE Asian waters. These localities are distributed among 3 large marine ecosystems, i.e. East China Sea, Kuroshio Current and South China Sea. See text for further description and Table 1 for abbreviations of each site

North Taiwan: North Taiwan is located in the subtropical region with mixed semi-diurnal tides of maximum range $2.5 \mathrm{~m}$. Sampling was conducted in June 2004. Waters around the north coast (Yeliou [YL], Badoutz [BAD], Bitou Cape [BTC] and Sandiu Cape [SDC]) are under the influence of the cold, upwelling eddy from the East China Sea Shelf generated by the Kuroshio Current and the warm waters from the Taiwan Strait (see Chiang et al. 1997) (Fig. 1, Table 1). Sampling was not conducted on the west coast of Taiwan, as the major habitats there are mangroves and estuarine soft shores.

East Taiwan: The east coast (Lai Lai [LL], Beiguan $[B Q]$, Three Fairy Platforms [TFP], Hsiao Yeliou [HYL] and Lanyu [LY]; sampled during June 2004) faces the Pacific Ocean, which is influenced by the warm Kuroshio Current (Fig. 1, Table 1) (Liang et al. 2003). The rocks are both sedimentary and volcanic. All the shores are oceanic and the salinity of the inshore seawater ranges from 30 to $33 \%$.

South China: In Xiamen, mainland China, sampling was conducted at 2 islands near Baiyu (BY) and Wuyu (WY) (June 2005) (Fig. 1, Table 1), facing the Taiwan Strait. The hydrology of Xiamen waters is influenced mainly by the South China Sea Surface Current from the south and the China Coastal Current from the north (Hu et al. 2002). The oceanographic currents affecting the waters in the Taiwan Strait are also influenced by the seasonal monsoons. Under the southwest monsoon, the water in the Taiwan Strait is mainly from the South China Sea Surface Current (summer) and the Kuroshio Current (spring), which enter the strait from the Penghu Channel (Jan et al. 2002). In winter, the water in the strait is influenced by the China
Coastal Current, which flows southward under the effect of the northeast monsoons. The entry of the South China Sea Surface Current and the Kuroshio Current is blocked at the Penghu Channel during the winter months (Jan et al. 2002). The shore at Xiamen is composed of volcanic rocks.

Hong Kong is within the tropics (Table 1), but with a seasonal climate. Mean air temperature ranges from $35^{\circ} \mathrm{C}$ in summer to $10^{\circ} \mathrm{C}$ in winter. Mean seawater temperature is around $28^{\circ} \mathrm{C}$ in summer and $15^{\circ} \mathrm{C}$ in winter. The water of the east coast of Hong Kong is oceanic, with a salinity of $33 \%$ in winter and $25 \%$ in summer. Hydrography is influenced by the South China Sea Surface Current in summer, and by a combination of the Taiwan Current and the Kuroshio Current in winter (Fig. 1). Rocky shores are mainly composed of granite or volcanic rocks. Tides are semi-diurnal with maximum tidal range $2.5 \mathrm{~m}$. Sampling was conducted at Shek Mei Tau (SMT) and Cape d'Aguilar (CD). Data were also taken from Chan et al. (2001), which covered 10 rocky shores in Hong Kong using the same sampling method as that used in the present study (Table 1).

To study the variation in seawater temperature and upwelling intensity of the study sites, monthly seawater temperature and upwelling indexes (from 2004 to 2006) were obtained from the NOAA Fisheries server (http://las.pfeg.noaa.gov/), which provides satellite environmental data on seawater temperature, and energy recovery device (ERD) derived upwelling indexes for Honshu (KOM, KAT, SHI, SHA), Okinawa, North Taiwan, East Taiwan and South China (Xiamen and Hong Kong). Due to resolution limitations, separate single sets of data were used to represent sites within Okinawa, Taiwan, Xiamen and Hong Kong. Variation in the seawater temperature and upwelling index from each site was analysed using multivariate analysis by PRIMER 6 (Plymouth Routines In Multivariate Ecological Research, PRIMER-E). A similarity matrix of the seawater temperature and upwelling index between locations was assessed using Euclidean Distance similarity test, followed by non-metric MultiDimensional Scaling (nMDS) plots.

Distribution pattern. At each study site, a $30 \mathrm{~m}$ stretch of coast was chosen. Four horizontal transects $(30 \mathrm{~m})$ were conducted at vertical intervals of $50 \mathrm{~cm}$ from 1 to $2.5 \mathrm{~m}$ above chart datum (CD), which covered the whole vertical range of Tetraclita spp. At each tidal level, 10 random $25 \times 25 \mathrm{~cm}$ quadrats were photographed using a photoframer (Chan et al. 2001). 
The percentage cover of all barnacle species in each quadrat photograph was identified and scored using the image analysis software SigmaScan (SPSS). From the photographs Tetraclita could be identified and sorted into species based on the colour differences on the parietes (Chan 2001, Chan et al. 2007a,b). Additional samples were collected from each site and dissected to examine the opercular plates for species identification and confirmation (see morphological identification of Tetraclita spp. in Chan 2001, Chan et al. $2007 a, b, c)$. Vertical distribution patterns of Tetraclita spp. were studied by calculating the mean abundance of each species at different tidal levels $(n=10$, $\pm 1 \mathrm{SD}$ ). Geographical variation in the mean abundance of each Tetraclita species from each site (taking the average of the abundance at the 2 tidal levels which showed highest abundance, i.e. $\mathrm{n}=20$ ) was analysed using multivariate analysis by PRIMER 6 . Due to the limited quantity, we excluded the data collected from LY in the multivariate analysis. All sampling sites were surveyed once only because the present study focuses on comparing the latitudinal differences but not on temporal variations. The 18 geographical locations were used as samples, and the abundance of the Tetraclita spp. at each location were used as variables. The square root was determined for all data and the similarity matrix of the Tetraclita spp. abundance between locations was assessed using the Bray-Curtis similarity test, followed by cluster analysis and NMDS plots. Bubble plots were generated to show the abundance pattern of Tetraclita spp. among the geographical locations. Analysis of similarities (ANOSIM) was conducted to investigate the variation in species composition between the hydrographic regions including Honshu (KAT, KOM, SHA, SHI), Okinawa (SDK, YK), North Taiwan (YL, BAD, BTC, SDC), East Taiwan (HYL, TFP, LL, BQ) and South China (CD, SMT, WY, BY). Similarity percentage (SIMPER) analysis was conducted to test the percentage contribution of each Tetraclita species to the total difference in species composition between the paired hydrographic regions.

\section{RESULTS}

\section{Oceanographic variations in the study sites}

Summer seawater temperatures (August to September) of all sites ranged from 26 to $30^{\circ} \mathrm{C}$. KOM and SHI, located in Honshu, Japan, had lowest summer temperatures among all sites studied (Fig. 2A), ranging from 26 to $27^{\circ} \mathrm{C}$. Xiamen and Hong Kong, located in South China, had highest summer seawater temperatures, reaching $30^{\circ} \mathrm{C}$ (Fig. 2A). In winter, KOM and SHI had the lowest seawater temperature, reaching $14^{\circ} \mathrm{C}$ in January and February (Fig. 2A). Winter seawater temperature in Taiwan, Hong Kong and Xiamen ranged from 16 to $18^{\circ} \mathrm{C}$ (Fig. 2A). Okinawa, however, had the highest winter seawater temperature of $23^{\circ} \mathrm{C}$ (Fig. 2A). In the nMDS ordination plot of the seawater temperature in the study sites, ordinations of Honshu were clustered together (Fig. 3A). The ordinations of Hong Kong, Taiwan and Xiamen were also grouped together, while the ordination of Okinawa was separated from the other groups (Fig. 3A).

Occurrence of upwelling followed seasonal cycles, with stronger upwelling in summer months (April to September, Fig. 2B). The locations in Honshu, Japan, had a higher upwelling index through the year (Fig. 2B), compared to Taiwan, Xiamen and Hong

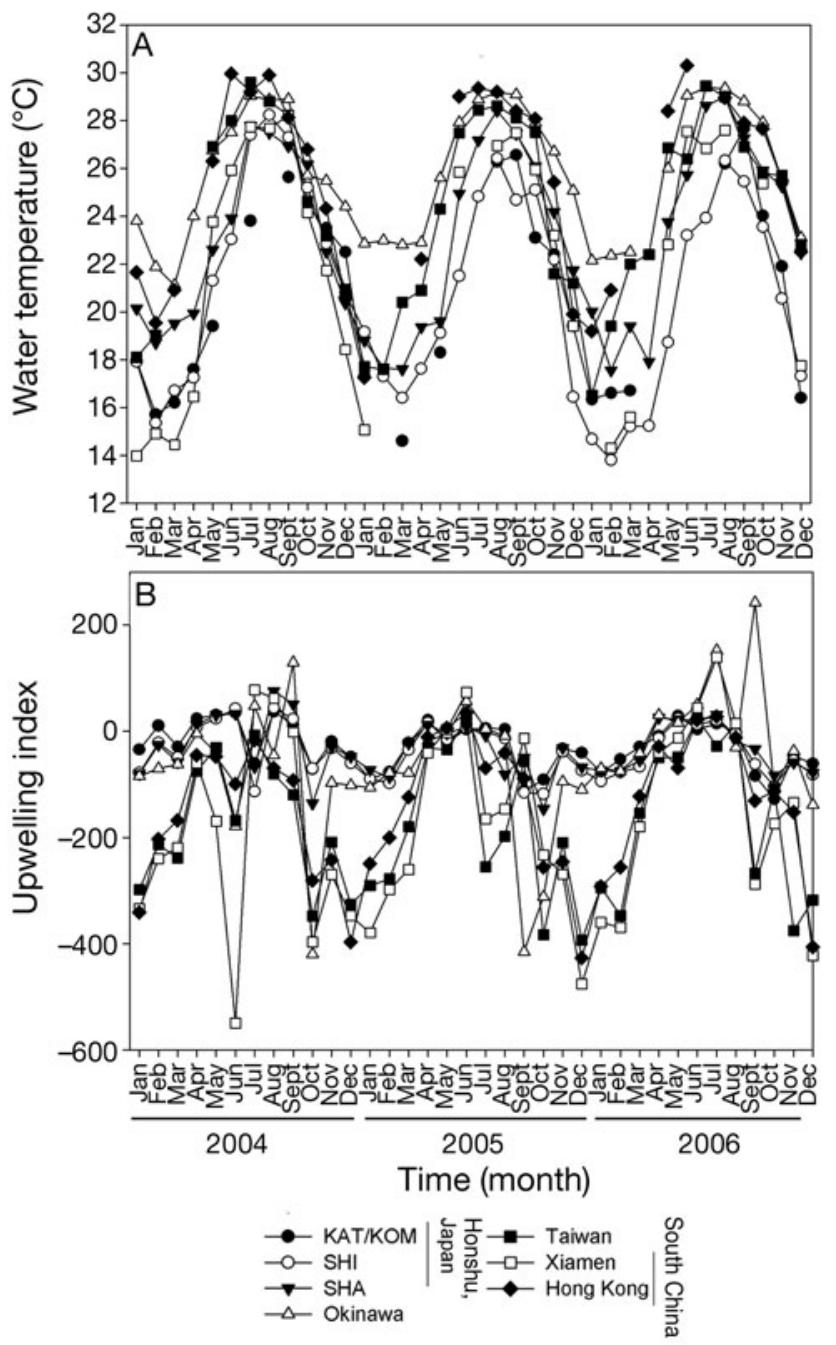

Fig. 2. Monthly variation in (A) seawater temperature and (B) upwelling index of the study sites (see Table 1 for definition of abbreviations) from 2004 to 2006. Data obtained from the NOAA Pacific Fisheries Laboratory. Gaps in lines indicate no data were available in that period 
Kong (Fig. 2B). Okinawa, however, had the highest peak of upwelling during August 2004 and 2006 (Fig. 2B). From the nMDS ordination of the upwelling index of the study sites, Honshu ordinations are clearly clustered in one patch (Fig. 3B), whilst ordinations of Xiamen, Hong Kong and Taiwan are clustered in a second patch (Fig. 3B). The Okinawa ordination was separated from the other 2 patches (Fig. 3B).

\section{Geographical and vertical distribution}

Tetraclita spp. exhibited significant variation in species composition among the geographical locations studied (ANOSIM result: $\mathrm{R}=0.873, \mathrm{p}<0.001$, Table 2 ). Among the 4 taxa $T$. squamosa was only recorded in South China regions (Hong Kong and Xiamen) (see SIMPER analysis in Table 2); T. japonica formosana dominated in Taiwan (Table 2), T. kuroshioensis existed along the Kuroshio Current shoreline, and T. j. japonica mostly occurred in Honshu, Hong Kong and Xiamen (Fig. 4). The diagnostic species revealed from SIMPER analysis that separates paired site

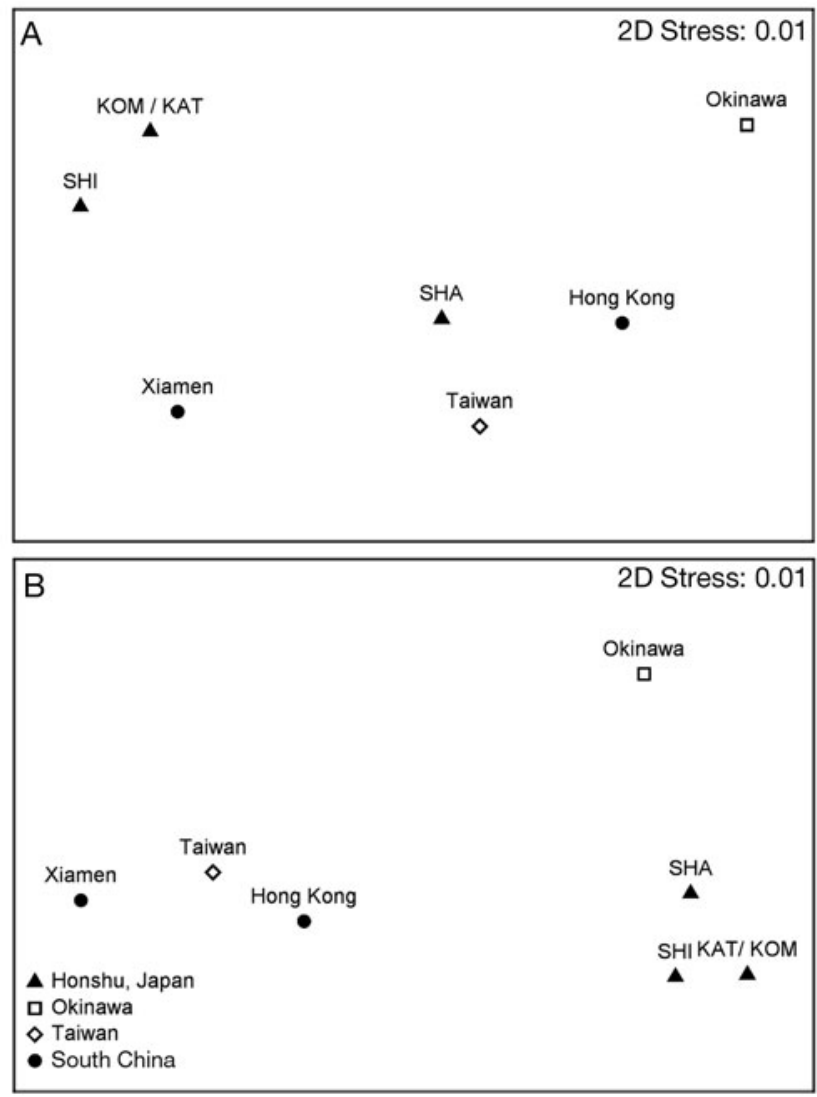

Fig. 3. nMDS plots of monthly (A) seawater temperature and (B) upwelling index of Honshu (KAT, KOM, SHI, SHA; see Table 1), Okinawa, Taiwan and South China (Xiamen and Hong Kong) groups can be seen in Table 2. Except in Xiamen and Hong Kong where the T. squamosa and T. j. japonica showed vertical zonation, little evidence of vertical separation of Tetraclita spp. was found (Table 3).

In Honshu, Japan, Tetraclita japonica japonica was an abundant barnacle on the mid shores (1.5 to $2 \mathrm{~m}$ above CD) of KAT and KOM (Boso Peninsula), SHI (Kii Peninsula) and SHA (Izu Peninsula), reaching $\sim 30$ to $50 \%$ cover (Fig. 4, Table 3). In contrast, T. j. formosana and T. kuroshioensis occurred in lower abundance in Honshu. All of these 3 Tetraclita spp. occurred in the same tidal zone and did not show distinct zonation patterns. The vertical range of $T$. $j$. japonica is $\sim 0.5 \mathrm{~m}$ (Fig. 4, Table 3).

In SED and YK at Okinawa, Tetraclita kuroshioensis was the most abundant species, reaching $\sim 20 \%$ cover on the mid shore (Table 2). T. japonica formosana existed in the same vertical range, but occurred at a very low abundance of $<5 \%$. No $T$. $j$. japonica were recorded (Fig. 4).

On the east coast of Taiwan (BQ, HYL and TFP), Tetraclita japonica formosana was common in the mid shore (1.5 to $2 \mathrm{~m}$ above CD), with $\sim 25 \%$ cover, whilst T. kuroshioensis had a low abundance of $<10 \%$ cover (Fig. 4). In LY, an exposed Pacific island, only a few $T$. j. formosana were sampled around the whole island. On the northeast coast (LL, SDC, BTC, BAD and YL), $T$. kuroshioensis and $T$. $j$. formosana were recorded (Fig. 4). T. kuroshioensis was the most abundant species, occupying $\sim 25 \%$ cover on the shore (Fig. 4 ). The abundance of $T . j$. formosana in YL was $\sim 10 \%$, which was lower than the east coast population. At YL, $T$. j. japonica had a very low abundance with a cover $<5 \%$ (Fig. 4) and was absent from other sites in Taiwan. The 3 species did not occupy different vertical ranges and were mixed in the same intertidal region (Fig. 4, Table 2).

Only Tetraclita squamosa and T. japonica japonica were recorded in Xiamen and Hong Kong, and the 2 species showed distinct vertical zonation (Fig. 4, Table 2). One-way ANOVA on the abundance of $T . j$. japonica along the 4 tidal levels studied $(1,1.5,2$, and $2.5 \mathrm{~m}$ above $\mathrm{CD}$ ) showed that this species was common on the high shores $(>1.75 \mathrm{~m} \mathrm{CD})$, reaching $\sim 40 \%$ cover (Xiamen, WY: $[F]_{3,36}=187, \mathrm{p}<0.05$, StudentNewman-Keuls [SNK] tests on tidal levels: $2>2.5>$ $1.5>1$; Xiamen, BY: $F_{3,36}=174, \mathrm{p}<0.05$, SNK tests: $2>$ $2.5=1.5>1$; Hong Kong, CD: $F_{3,36}=185, \mathrm{p}<0.05$, SNK tests: $2=1.5>2.5=1$; SMT: $F_{3,36}=196$, SNK tests: $1.5>2>2.5=1$ ), whilst $T$. squamosa was abundant on the low shores $(<1.5 \mathrm{~m} \mathrm{CD}, 1$-way ANOVA: Xiamen, WY: $F_{3,36}=188, \mathrm{p}<0.05$, SNK tests: $1>1.5=2=2.5$; Xiamen BY: $F_{2,27}=17.9, \mathrm{p}<0.05$, SNK tests: $1>1.5=2$ [T. squamosa only occurred at the 2 lowest tidal levels in Hong Kong; therefore no statistical analysis was 


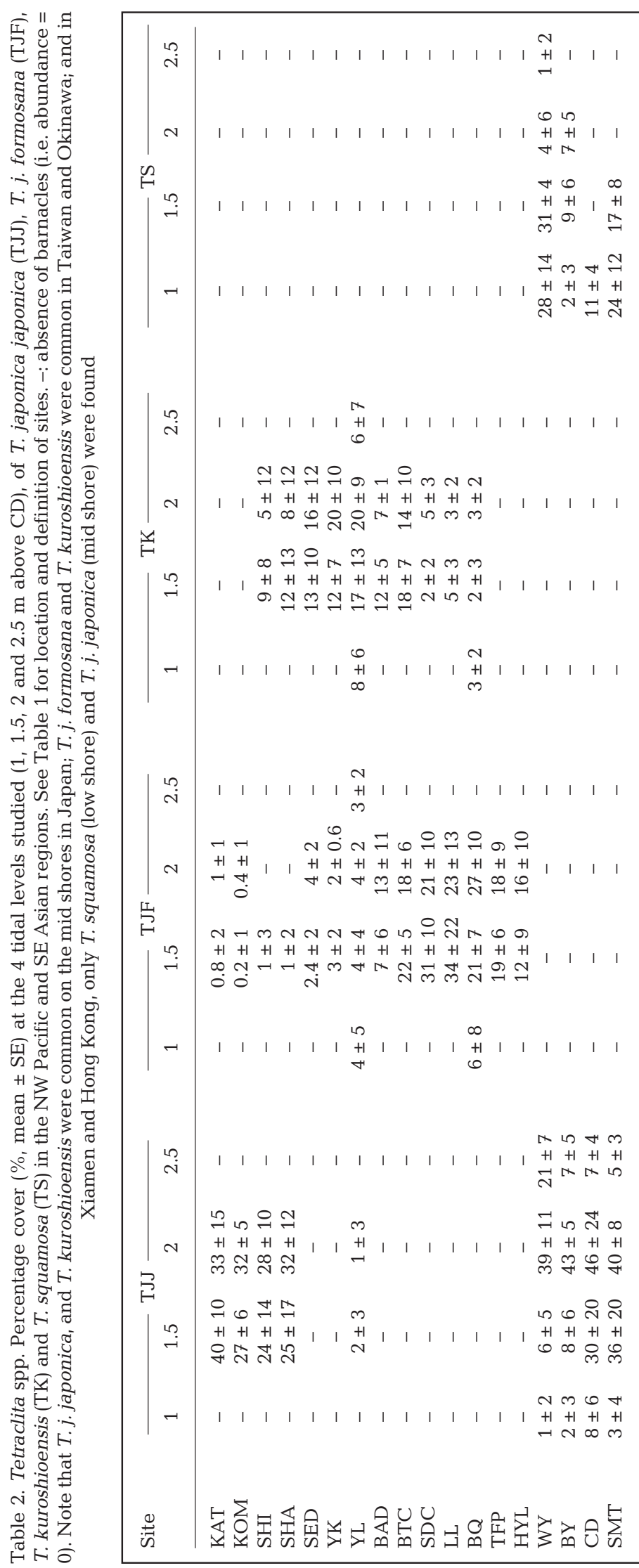

conducted to compare with the high shore abundance]). No T. $j$. formosana or T. kuroshioensis was observed in Hong Kong or Xiamen (Fig. 4, Tables 2 \& 3).

Based on nMDS plots (Fig. 5A) and similarity tree by cluster analysis (Fig. 5B), 4 geographical location groups separated at $60 \%$ similarity were identified: Honshu, North Taiwan and Okinawa, East Taiwan, and South China groups. Tetraclita japonica formosana was the most abundant species in the East Taiwan group (Fig. 5F), whilst $T$. $j$. japonica showed high abundance in the Honshu and South China groups (Fig. 5C). T. squamosa showed distribution in the South China group, whilst T. kuroshioensis was common in the Honshu, Okinawa and North Taiwan groups (Fig. 5D,E).

\section{DISCUSSION}

\section{Geographical distribution}

Tetraclita spp. showed distinct variations with latitudinal gradient in geographical distribution, abundance and zonation pattern. In Japan, where T. kuroshioensis, T. japonica japonica and T. j. formosana co-existed, they did not show different zonation patterns, whilst in the southern locations (Xiamen and Hong Kong), T. j. japonica and T. squamosa occupied distinct zones, with T. $j$. japonica in the mid to high shore and T. squamosa in the low shore. The vertical distribution range of Tetraclita spp. was also higher in Hong Kong and Xiamen than Okinawa, Taiwan and Japan.

nMDS ordination of Tetraclita spp. composition among the geographical locations matched with the ordination patterns of the seawater temperature and upwelling index (Figs. 2 \& 5), suggesting that geographical distribution of Tetraclita spp. could be influenced by hydrographic regimes. Differences in oceanographic currents may result in variation in larval dispersal and hence geographical distribution of Tetraclita spp. along the latitudinal gradient from Japan to Hong Kong (see Morgan 2001, Herbert et al. 2007). The brooding season of Tetraclita spp. occurs in summer as high temperature is essential to initiate gonad development (Hines 1978, Chan \& Williams 2004) (Fig. 2) and, therefore, the larvae of Tetraclita spp. are probably transported by the summer oceanographic currents in the Asian region. T. kuroshioensis and T. japonica formosana exist only in Japan, Okinawa and Taiwan. The highest abundance of $T$. $j$. formosana on the east coast of Tai- 

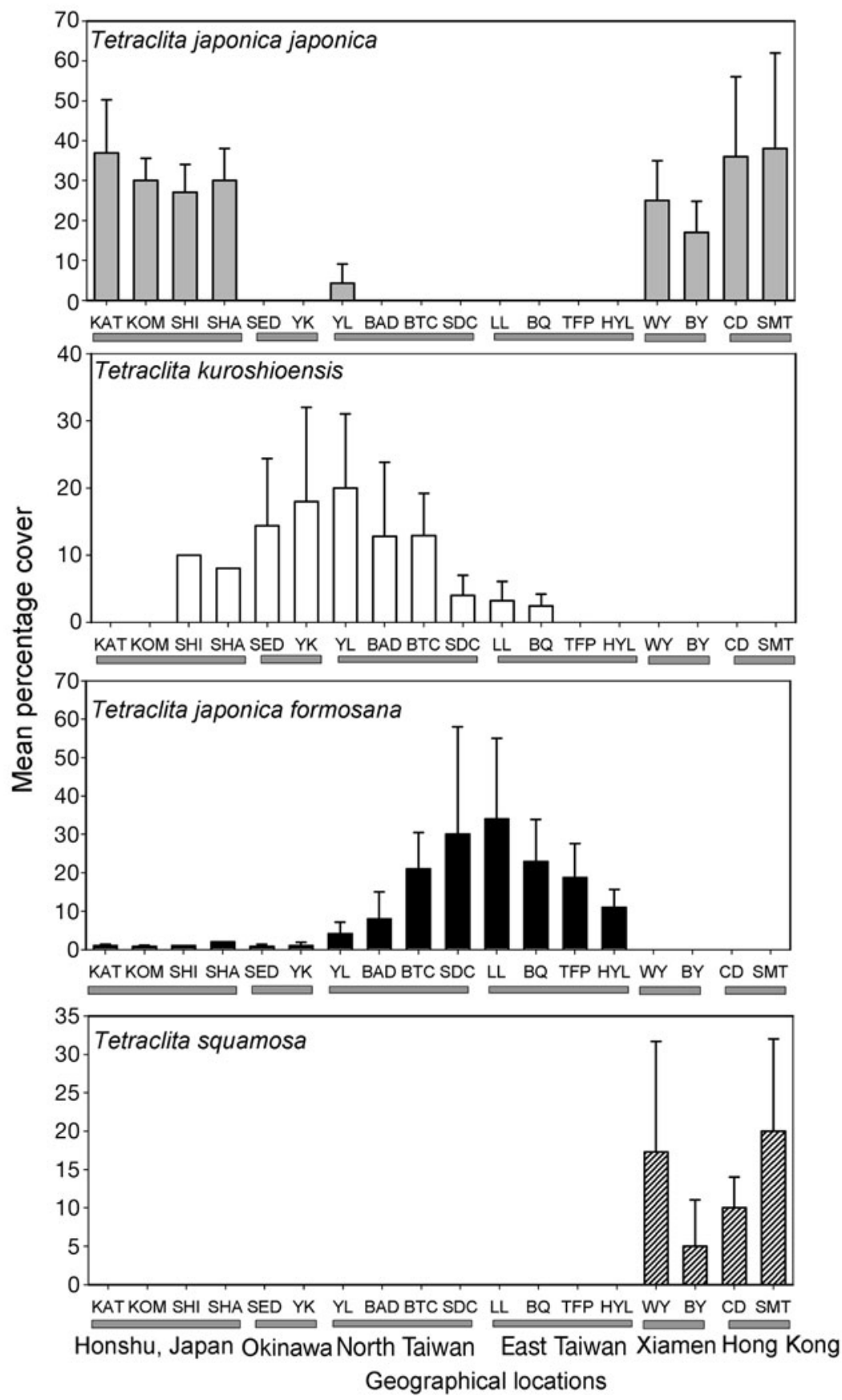

Fig. 4. Tetraclita spp. Geographical distribution (mean \% cover $\pm 1 \mathrm{SD}$ ) of 4 species in the NW Pacific and SE Asian waters. Grey horizontal bars beneath site abbreviations represent site groupings in different hydrographic regions (see Table 1)

wan suggests that the larvae of $T$. $j$. formosana are transported by the Kuroshio Current flowing along the eastern coastline of Taiwan in summer (see Lee \& Chao 2003, Liang et al. 2003). The complete larval development period for Tetraclita spp. was $\sim 14 \mathrm{~d}$ under laboratory conditions (Chan 2003) and the speed of the Kuroshio Current was estimated to be $\sim 6.4 \mathrm{~km} \mathrm{~h}^{-1}$ (Makoto 1989). As a result, Tetraclita spp. larvae could probably travel at least $2000 \mathrm{~km}$ (i.e. $14 \mathrm{~d} \times$ $6.4 \mathrm{~km} \times 24 \mathrm{~h}$ ) in $14 \mathrm{~d}$ when transported by the Kuroshio Current. This geographical distance covers the region from Taiwan to Wakayama in Honshu, Japan (which matched with the geographical distribution of T. kuroshioensis in the present study). T. j. formosana was absent from the South China Sea and the Taiwan Strait probably because these waters are not affected by the Kuroshio Current during summer (see Jan et al. 2002). T. j. japonica had high abundance at Honshu, Hong Kong and Xiamen. The low abundance of T. j. japonica in Taiwan and Okinawa, which is in between Japan, Hong Kong and Xiamen, suggests that there may be a physical and genetic boundary between the northern and southern populations in the Pacific Ocean. The larval pool of $T$. $j$. japonica in Japan may be associated with the Kuroshio Current, whilst the larval pool in South China is associated with the South China Sea Surface Current. T. squamosa had high abundance along the southern mainland China coast, suggesting that the larval pools are related to the South China Sea Surface Currents (Jan et al. 2002, Lee \& Chao 2003).

\section{Vertical zonation and abundance}

Variation in the vertical zonation patterns of Tetraclita spp. along the latitudinal gradient from Japan to Hong Kong could result from the interactions of the rock types, climate and postsettlement mortality (Raimondi 1988, Miron et al. 1999). The rock types in Taiwan, Okinawa and Japan are mainly fine, porous volcanic and sedimentary, whilst common rock types of Hong Kong shores are relatively smooth, hard granite and volcanic. During the summer, rock surface temperature in Japan, Taiwan and Okinawa may be lower than that on the granite and volcanic rocks in Hong Kong and Xiamen (rock surface temperature in summer in Hong Kong can reach up to $50^{\circ} \mathrm{C}$ when emersed and is similar to seawater temperature when submerged; Chan \& Williams 2003, Chan 
Table 3. Tetraclita spp. Global test (showing $\mathrm{R}_{i} \mathrm{p}<0.001$ ) and SIMPER analysis for pairwise comparison of species composition (\%) between hydrographic regions (see Table 1 for site names). Diagnostic species which contributed $>25 \%$ difference between regions are shown with their percentage contribution. TK: T. kuroshioensis; TJJ: T. japonica japonica; TJF: T. j. formosana; TS: T. squamosa

\begin{tabular}{|lccccc|}
\hline & TK & TJJ & TJF & TS & R \\
\hline Okinawa & & & & & \\
Honshu & 35 & 57 & - & - & 1 \\
East Taiwan & 40 & 59 & - & - & 0.93 \\
South China & - & 43 & - & 29 & 0.99 \\
North Taiwan & & & & & \\
Honshu & 32 & 41 & - & - & 0.97 \\
Okinawa & 33 & - & 58 & - & 0.45 \\
East Taiwan & 55 & - & 37 & - & 0.531 \\
South China & 28 & 33 & - & 30 & 0.99 \\
East Taiwan & & & & & \\
Honshu & - & 58 & 33 & - & 0.99 \\
Okinawa & 40 & - & 59 & - & 0.93 \\
South China & - & 39 & 30 & 26 & 0.99 \\
South China & & & & & \\
Honshu & - & 31 & - & 65 & 0.74 \\
Okinawa & - & 43 & - & 29 & 0.99 \\
East Taiwan & - & 39 & 30 & 26 & 0.99 \\
\hline
\end{tabular}

et al. 2006). In Hong Kong, the vertical settlement ranges of $T$. squa mosa and $T$. japonica japonica are similar, and spat settled in the same vertical range. In the mid shore, T. squamosa settlers suffered higher mortality compared with $T$. j. japonica (Chan \& Williams 2003), thus confining them to a lower shore region in Hong Kong. In northern geographical locations, T. kuroshioensis, T. j. japonica and T. j. formosana, which settled on the mid shores, can probably still survive, resulting in a mixture of Tetraclita species in the same tidal zone. Mortality could occur very early after settlement, when the settlers are still in cyprid stage (Glenner \& Høeg 1993) and such mortality could vary among different barnacle species. Settlement pattern of barnacles could be affected by the variation in biofilm assemblages (Qian et al. 2003). Balanus amphitrite, for example, settles intensely on areas which contain biofilms that grow on the mid shores of the intertidal region (Qian et al. 2003, Thiyagarajan et al. 2006). Variation in biofilm assemblage among geographical regions could be another factor affecting the geographical variation in zonation pattern of Tetraclita spp. Further studies should compare the settlement patterns and post-settlement mortality of Tetraclita spp. among the geographical regions to test whether
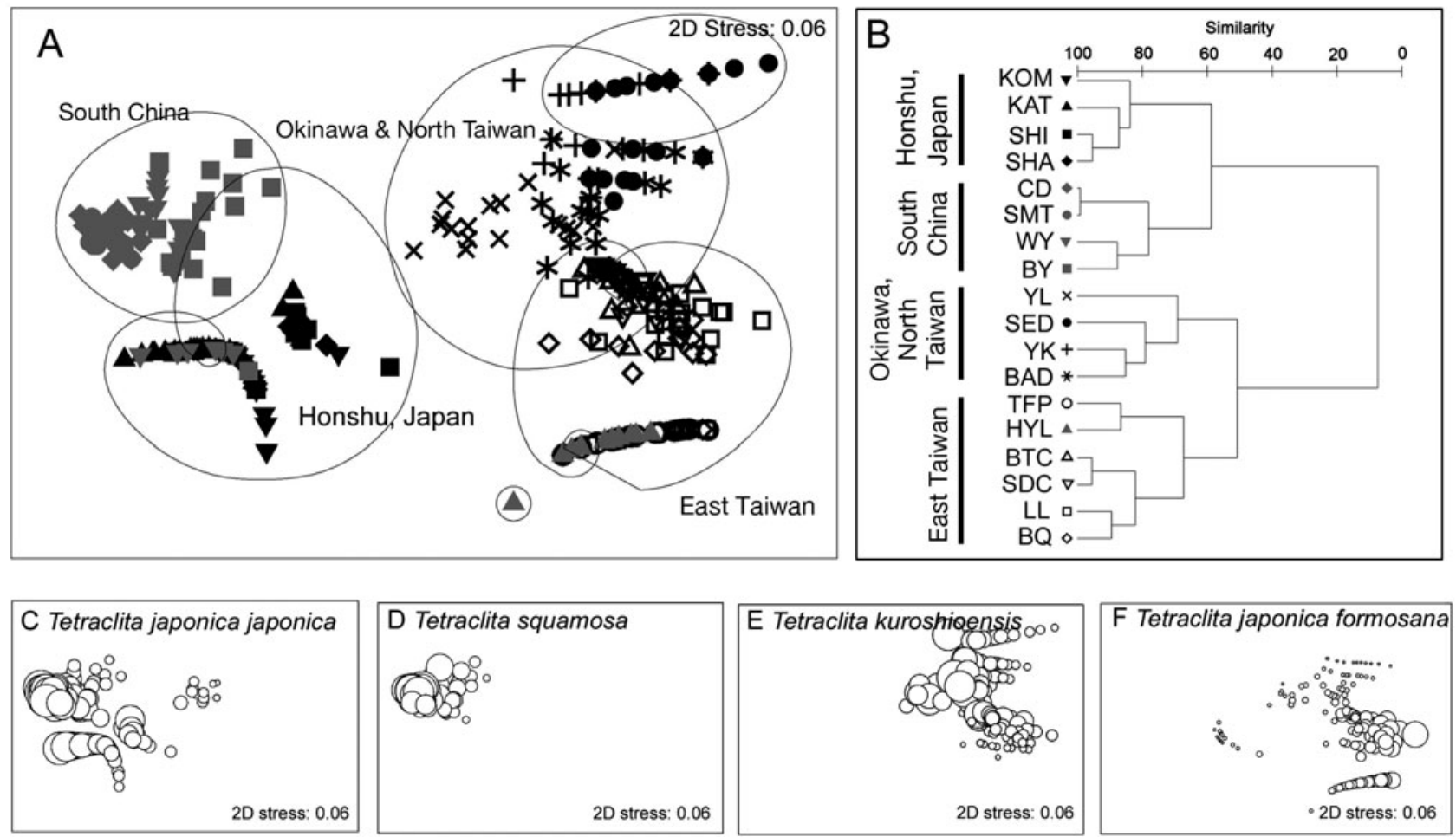

Fig. 5. Tetraclita spp. Multivariate analyses of the distribution pattern in the NW Pacific and SE Asian waters: (A) nMDS plot, (B) similarity tree by cluster analysis, (C-F) bubble plots of abundance patterns for each Tetraclita species. (LY data were excluded from the analysis due to the low abundance of barnacles). See Table 1 for location and definition of sites 
Tetraclita spp. in northern locations suffer lower settlement mortality, which results in a mixture of species at the same tidal levels.

The percentage cover of Tetraclita spp. on the Pacific coast (Japan, Okinawa and Taiwan) is lower than the populations on the mainland China coast (Hong Kong and Xiamen). Variation in barnacle density among locations is related to upwelling and variation in predation pressure. Strong upwelling in summer months has been reported to exist along the coastline of Izu Peninsula in Japan, the northeastern coastline of Taiwan and the Okinawa Island (Ishizaka et al. 1992, Ito et al. 1995, Lee \& Chao 2003) (Fig. 2B). Upwelling can carry larvae out to the open ocean and thereby reduce recruitment density and frequency (Connolly et al. 2001). Lower barnacle density on the coastline in Japan, Taiwan and Okinawa may result from the effect of upwelling (Ito et al. 1995).

Variation in barnacle abundance between geographical locations can also result from differences in predation pressures. In Hong Kong and Xiamen the major predators in the intertidal zone are the muricid gastropods Thais clavigera and Morula musiva (Morton \& Morton 1983). On the NW Pacific coast, the predators in the intertidal zone include the muricid gastropods (Utinomi 1971) and, with high diversity and abundance, the porcupine fish Diodon spp., which can feed intensely on barnacles (Masuda et al. 1984). The lower abundance of Tetraclita spp. in the Pacific shores compared to the mainland China coast may result from variation in predation pressure along the latitudes.

The intertidal acorn barnacle Tetraclita spp. has a high diversity of species in the waters of the NW Pacific and South China. The present study indicates that the distribution of Tetraclita spp. varies along the latitudes, and similarity of species assemblages can be grouped into 4 geographical regions, including the Pacific coast of Japan, North Taiwan and Okinawa, East Taiwan, and South China waters. Such geographical distribution of Tetraclita spp. could be influenced by the oceanographic currents (Kuroshio Current and the South China Sea Surface Current) which drive the larval pools into these 4 distinct geographical regions. Variation in abundance and zonation of Tetraclita spp. along the latitudes may be a result of interactions of upwelling patterns, climate and settlement biology. Further studies should focus on the population genetics and phylogeography of Tetraclita spp. in the Asian region to reveal the connections among the geographical populations.

Acknowledgements. The authors thank A. J. Southward (Marine Biological Association, UK) and K. J. Caley (University of Nottingham, UK) for comments on the manuscript. Thanks also to T. Yamaguchi (Chiba University, Japan), Prof. M. Yam- aguchi (University of the Ryukyus, Japan), M. Liu (The University of Hong Kong), S. Tsang and J. Chan for providing assistance with the fieldwork. The authors also thank the 4 anonymous reviewers who provided constructive comments to improve the quality of the manuscript. This study was partially supported by grants from the Research Grants Council, Hong Kong SAR (Project no. HKU7597/05M), the National Science Council, Taiwan, ROC (NSC 96-2621-B-001-007-MY3) and a research travel grant in Academia Sinica, Taiwan, ROC.

\section{LITERATURE CITED}

Chan BKK (2001) Studies on Tetraclita squamosa and Tetraclita japonica (Cirripedia: Thoracica) I: adult morphology. J Crustac Biol 21:616-630

Chan BKK (2003) Studies on Tetraclita squamosa and Tetraclita japonica (Cirripedia: Thoracica) II: larval morphology. J Crustac Biol 23:522-547

- Chan BKK, Williams GA (2003) The impact of physical stress and molluscan grazing on the settlement and recruitment of Tetraclita species (Cirripedia: Balanomorpha) on a tropical shore. J Exp Mar Biol Ecol 284:1-23

Chan BKK, Williams GA (2004) Population dynamics of the acorn barnacles, Tetraclita squamosa and Tetraclita japonica (Cirripedia: Balanomorpha), in Hong Kong. Mar Biol 146:149-160

Chan BKK, Morritt D, Williams GA (2001) Effect of salinity and recruitment on the distribution of Tetraclita squamosa and Tetraclita japonica (Cirripedia: Balanomorpha) in Hong Kong. Mar Biol 138:999-1009

Chan BKK, Morritt D, De Pirro M, Leung KMY, Williams GA (2006) Summer mortality: effects on the distribution and abundance of the acorn barnacle Tetraclita japonica on tropical shores. Mar Ecol Prog Ser 328:195-204

Chan BKK, Tsang LM, Chu KH (2007a) Morphological and genetic differentiation of Tetraclita squamosa (Crustacea, Cirripedia) in East Asia and description of a new species of Tetraclita. Zool Scr 36:79-91

Chan BKK, Tsang LM, Chu KH (2007b) Cryptic diversity of Tetraclita squamosa complex (Crustacea, Cirripedia) in Asia: description of a new species from Singapore. Zool Stud 46:46-56

Chan BKK, Tsang LM, Ma KY, Hsu CH, Chu KH (2007c) Taxonomic revision of the acorn barnacles Tetraclita japonica and Tetraclita formosana (Crustacea: Cirripedia) in East Asia based on molecular and morphological analyses. Bull Mar Sci 81:101-113

Chiang KP, Shiah FK, Gong GC (1997) Distribution of summer diatom assemblages in and around a local upwelling in the East China Sea northeast of Taiwan. Bot Bull Acad Sinica 38:121-129

Connolly SR, Menge BA, Roughgarden J (2001) A latitudinal gradient in recruitment of intertidal invertebrates in the northeast Pacific Ocean. Ecology 82:1799-1813

Glenner H, Høeg JT (1993) Scanning electron microscopy of metamorphosis in four species of barnacles (Cirripedia Thoracica Balanomorpha). Mar Biol 117:431-439

Hasegawa T, Yamaguchi T, Kojima S, Ohta S (1996) Phylogenetic analysis among three species of intertidal barnacles of the genus Tetraclita (Cirripedia: Balanomorpha) by nucleotide sequences of a mitochondrial gene. Benthos Res 51:33-39

Herbert RJH, Southward AJ, Sheader M, Hawkins SJ (2007) Influence of recruitment and temperature on distribution of intertidal barnacles in the English Channel. J Mar Biol Assoc UK 87:487-499 
Hines AH (1978) Reproduction in three species of intertidal barnacles from central California. Biol Bull 154:262-281

Hiro F (1939) Studies on the cirripedian fauna of Japan IV. Cirripedes of Formosa (Taiwan) with some geographical and ecological remarks on the littoral forms. Mem College Science Kyoto Imp Univ Ser B 15:245-284

Hu J, Kawamura H, Hong H, Pan W (2002) A review of research on the upwelling in the Taiwan Strait. Bull Mar Sci 73:605-628

Ishizaka J, Fukushima H, Kishino M, Saino T, Takahashi M (1992) Phytoplankton pigment distributions in regional upwelling around the Izu Peninsula detected by coastal zone colour scanner on May 1982. J Oceanogr 48:305-327

Ito T, Kaneko A, Furukawa H, Gohda N, Koterayama W (1995) A structure of the Kuroshio and its related upwelling on the East China Sea Shelf slope. J Oceanogr 51: 267-278

Jan S, Wang J, Chern CS, Chao SY (2002) Seasonal variation of the circulation in the Taiwan Strait. J Mar Syst 35: 249-268

Lee HJ, Chao SY (2003) A climatological description of circulation in and around the East China Sea. Deep-Sea Res II 50:1065-1084

Liang WD, Tang TY, Yang YJ, Ko MT, Chuang WS (2003) Upper-ocean currents around Taiwan. Deep-Sea Res II 50:1085-1105

Makoto T (1989) Recent large-scale changes in the biomass of the Kuroshio Current Ecosystem. In: Sherman K, Alexander LM (eds) Biomass yields and geography of large marine ecosystems. AAAS Selected Symposium 111. Westview Press, Boulder, CO, p 37-65

Masuda H, Amaoka K, Araga C, Uyeno T, Yoshino T (eds) (1984) The fishes of the Japanese Archipelago, Vol 1. Tokai University Press, Tokyo

Miron G, Boudreau B, Bourget E (1999) Intertidal barnacle distribution: a case study using multiple working hypotheses. Mar Ecol Prog Ser 189:205-219

Morgan SG (2001) The larval ecology of marine communities.

Editorial responsibility: Pei-Yuan Qian,

Kowloon, Hong Kong SAR
In: Bertness MD, Gaines SD, Hay M (eds) Marine community ecology. Sinauer Associates, Sunderland, MA, p 159-181

Morton B, Morton J (1983) The seashore ecology of Hong Kong. Hong Kong University Press, Hong Kong

Newman WA, Ross A (1976) Revision of the balanomorph barnacles; including a catalogue of the species. Memoir 9, San Diego Society of Natural History, San Diego, CA

Pilsbry HA (1916) The sessile barnacles (Cirripedia) contained in the collections of the U.S. national museum: including a monograph of the American species. Bull US Natl Mus 93:241-353

> Qian PY, Thiyagarajan V, Lau SCK, Cheung SCK (2003) Relationship between microbial community and the attachment of acorn barnacle Balanus amphitrite. Aquat Microb Ecol 33:225-237

Raimondi PT (1988) Rock type affects settlement, recruitment, and zonation of the barnacle Chthamalus anisopoma Pilsbry. J Exp Mar Biol Ecol 123:253-267

Ren X, Liu R (1979) Studies on Chinese Cirripedia (crustacean) II: Family Tetraclitidae. Oceanol Limnol Sin 10: $338-353$

Thiyagarajan V, Lau SCK, Cheung SCK, Qian PY (2006) Cypris habitat selection facilitated by microbial biofilms influences the vertical distribution of subtidal barnacle Balanus trigonus. Microb Ecol 51:431-440

Utinomi H (1949) Studies on the cirripedian fauna of Japan VI. Cirripedes from Kyusyu and Ryukyu Islands. Publ Seto Mar Biol Lab 1:19-37

Utinomi H (1954) Invertebrate fauna of the intertidal zone of the Tokara islands IX. Cirripedia. Publ Seto Mar Biol Lab 4:17-26

Utinomi H (ed) (1971) Coloured illustrations of seashore animals of Japan. Hoikusha, Osaka

Yamaguchi T (1987) Changes in the barnacle fauna since the Miocene and the infraspecific structure of Tetraclita in Japan (Cirripedia: Balanomorpha). Bull Mar Sci 41: $337-359$

Submitted: September 3, 2007; Accepted: February 13, 2008 Proofs received from author(s): June 18, 2008 